\title{
Czech Higher Education Policy: The Case of Accreditation
}

\author{
Jan Vašenda \\ University of Economics, Prague, Czech Republic \\ Faculty of Economics \\ Czech Republic
}

\begin{abstract}
There has been used a programme accreditation scheme as a main tool for quality assurance in the Czech higher education. Accreditation of higher education in Czech Republic has not primarily focused on quality assurance processes but rather on the quality of input into the teaching process. Empirical evidence shows that main reasons for not granting accreditation were unsatisfactory credentials of the academic staff and issues related to the proposed programme curriculum. The recently adopted amendment of the Higher Education Act introduces changes, which could mean a closer convergence towards the models used in the Western Europe or United States. However, it is hard to predict how the new accreditation system shall work in practice especially in terms of to the approach of the accreditation officials towards various universities and specific accreditation cases. Economic policy perspectives related to accreditation process, such as unemployment, economic regulation, principal-agent problem, Gresham's law, information asymmetry, and human capital theory are also discussed in the paper.
\end{abstract}

Keywords: Programme Accreditation, Institutional Accreditation, Czech Republic, Policy

\section{Introduction}

A rapid increase of students and a demand for regulation of new private higher education providers were the main driving forces for an introduction of compulsory accreditation, legally codified by Czech Higher Education Act No. 111/1998 Coll. (Šebková 2007; Kohoutek 2014). The period before, i.e. 1990 to 1998, may be called implicit accreditation (Šebková 2007) or experimental accreditation (Kohoutek 2014).

The accreditation scheme has been intensively discussed and criticized among the academic community and university representatives for many years, but the major changes, e.g. the concept of institutional accreditation have been implemented only recently by the Higher Education Act amendment, and the actual policy changes are still to be fully implemented into praxis.

The paper analyses the Czech accreditation system. The first section describes the system used in the Czech Republic up to the present time. The following section deals with the main shortcomings of the system and provides rationale for why it couldn't continue the same way. The analysis is supported by empirical evidence. The recently adopted Higher Education Act amendment is also considered, followed by a discussion regarding the role and value of accreditation. Economic policy perspectives related to accreditation process, such as unemployment, economic regulation, principal-agent problem, Gresham's law, information asymmetry, and human capital theory are also discussed in the paper.

\section{Accreditation in the Czech Republic-former system}

There has been used a programme accreditation scheme as a main tool for quality assurance in the Czech higher education. It means that a university was required to have accredited each programme or field of study separately by the Accreditation Commission to be eligible to offer and issue a diploma for the particular degree (e.g. Bc. or Mgr.) Although the accreditation was officially granted by the Ministry of Education, only in very exceptional cases $^{1}$ did the ministry overrule a recommendation of the Accreditation Commission of the Czech Republic

\footnotetext{
${ }^{1}$ The case of the Law Faculty, University of West Bohemia is the most famous example, when the ministry didn't respect the recommendation of ACCR. The ministry also didn't follow the ACCR's recommendations to withdraw the accreditation of the College of Banking and to limit the accreditation of The Jan Amos Komensky University. All the cases belong to the period of 2011 and 2012. 
(hereinafter 'Accreditation Commission' or 'ACCR'). Therefore, the ACCR was certainly an influential player. The members of Accreditation Commission were appointed by the government.

The former Czech accreditation system had two tier character. This means that every university degree consisted of a respective study programme and a field of study. A study programme was defined broadly and might contain more than one field of study.

Application for accreditation (or its expansion or extension) must have included information about certain features of the programme to be offered, specifically: Characteristics of the field of study (study programme); Profile of the graduate (including the occupational profile) and programme objectives; Number of accepted applicants to study in the academic year; Data regarding space, information and technical resources to support the study programme; Information about the programme curriculum and its structure; Description of all individual courses in the program including required and recommended literature; Information about the state exams, proposed thesis topics and defended theses topics examples; admission requirements; Scientific, research, development, artistic and other innovative activity related to study programme; Profiles of all academic staff members expected to teach in the programme with particular attention to their rank, selected recent publications (in the last 5 years), and also to the type and extent of their employment contract, comprehensive data about the academic staff must have been provided as well, e.g. total headcount of Full Professors (also their FTE), Associate Professors (also their FTE), Assistant Professors, Instructors, Assistants and other academic staff (Accreditation Commission Czech Republic 2014).

Universities were required to designate a guarantor for each programme submitted for (re)accreditation. The requirements were set by the Higher Education Act as follows: Guarantor of the study programme must hold a rank of Associate professor ('docent') or a Professor in the field of study in which she/he should be a guarantor of quality and development and the guarantor's publication or artistic activities within the last five years related to the guaranteed field are sufficient. She/he must have a full employment contractat the respective institution and his/her another employment at another institution cannot exceed a half-time workload. The guarantor could guarantee only one bachelor, one master and one doctoral study programme at a time (Accreditation Commission Czech Republic 2015).

ACCR would also assess whether the profile of the graduate (including the occupational profile), programme objectives, selection of required courses, content of the state exam and proposed final thesis topics were in mutual correspondence and thus create a coherent integral entity. In the recent years, however, the main consideration was on academic staff ranks (taking into account their recent publication record) and also on the credentials of the programme guarantor.

Finally, the ACCR also made recommendations on (not)granting a state consent to a legal entity wishing to operate as a private university. An application for the state consent must have also included a study programme(s) offered by the institution. The standards and requirements were basically the same as described above.

\section{Shortcomings of the former system and reasons for a change}

The former scheme of the programme accreditation caused administrative burden for the university administration as they needed to submit all the required information on every individual programme they wanted to accredit or re-accredit. Moreover, the provided information very often overlapped as many courses featured in various programmes and the same applies to many instructors. Two tier characteristic of programme accreditation made the system rather confusing and more complicated than anything else. What is the need for having study programmes divided into individual study fields of study. Besides, I believe that anywhere else in academic environment the expression 'field' has broader meaning than 'programme' unlike in the case of the Czech accreditation.

The main issue connected with the system was that ACCR focused primarily on inputs (i.e. academic staff ranks and their publications, programme and individual course description). Much less attention was paid to the process of internal quality assurance and the student learning outcomes. The fact that system was more focused on the inputs instead of considering the whole institutional performance was criticized by OECD experts already in their 2006 evaluation report (Šebková 2009).Another issue is that of the programme guarantor. The requirements for the programme guarantor were not favourable towards private universities. As mentioned before ranks of the academic staff teaching in the programme and especially credentials of the programme guarantor were the crucial attributes when the accreditation proposal was assessed by the ACCR. 
One disadvantage for private schools is that only public universities possess the right to appoint full professors or associate professors (which is the minimum requirement for the programme guarantor). No private university has this privilege. A university needs to have accreditation for appointing the professors and associate professors, which is again based on the requirement of having enough professors and associate professors.

The academic staff possessing a rank of the full professor or associate professor ('docent') are entitled to use their rank at all universities in the country unlike for instance in the case of the USA where the title is linked to the institution, which awarded the academic rank.

The requirement of having the internal full-time programme guarantor (prior 2011 an external guarantor was accepted) may be understandable in principle, yet it can actually prove quite problematic, as seen in the following examples from Czech academia. The idea was to avoid the situation that one university professor was guaranteeing programs at several institutions at the same time. The high profile full-time internal guarantor should be the one around whom the programme is built and developed. The same principle applies to the phenomena of so called 'turbo' professors featured at several programs in several universities at the same time while his/her total workload significantly exceeding plausible extent. A problem, however, may appear with regard to the decisionmaking process as the role of the programme guarantor has not been clear in that respect. An important factor to note here, is that the decision-making power has always been with the respective programme director (department chair, dean of the faculty offering the programme) so the role of the programme guarantor in terms of decisionmaking was rather a formality, as not necessarily the respective dean or chair always performed also the role of the programme guarantor. The need to have a programme guarantor may be seen as problematic also from another stand point. The ACCR was already assessing the programme content including the academic staff credentials, curriculum etc. so there was no need to have the requirement for the programme guarantor. Conversely, the highprofile programme guarantor is the one who should oversee and guarantee the quality of the programme so there shouldn't be a need to assess the program content for a second time as it would suggest that the role of the guarantor is again rather formal. Therefore, neither external nor internal programme guarantor is needed.Although the ranks of academic staff are important, and certainly are prerequisites for a good instruction (as academic staff members having higher academic ranks possess stronger academic experience and publication records) this, does not necessarily always guarantee better student learning outcomes (Alderman 2005).

Another potential problem may be described by the following example: Let's assume that a university professor teaches the same course (e.g. Foundations of economics) in similar programmes (e.g. Business administration) at two different universities. While a programme director at one university instructed the professor to require a certain level of the student performance, a programme director at another university might be satisfied with lower student effort and achievement. The 'value' of the same professor in the programme accreditation proposal of both universities, when assessed by ACCR, was the same (e.g. 0.5 FTE Professor) but the learning outcomes delivered by the professor might differ significantly.

Here is some empirical evidence of the ACCR recommendation standpoints. The negative recommendations made by ACCR between 2002 and 2016 are numbered and classified in the table below ${ }^{2}$. I've divided the reasons for not granting the accreditation (including expansion or extension) into 4 categories, i.e. academic staff, programme guarantor, curricular issues, and other reasons. The reasoning related to the individual programme accreditation cases mentioned in the reports published by ACCR (Akreditačníkomise Českárepublika - Zápisy ze zasedání, n.d.) might fall to more than one category. While between years 2010 and 2015, the most frequent reason claimed by ACCR were unsatisfactory credentials of the academic staff featuring in the respective programme, prior to that, from 2002 to 2009, ACCR was mostly concerned with the proposed programme curriculum and related issues. Reasons classified into the category Other were mainly unsatisfactory study guides for a combined form of study and technical (formal) flaws of the application. From the table data is also apparent that a programme guarantor became an issue only after the introduction of the internal programme guarantor requirement in 2011.

\footnotetext{
${ }^{2}$ Only bachelor and master programmes are considered, I did not consider accreditation of rigorous exams (so called 'small doctorate' leading to a degree $\mathrm{PhDr}$.), which is a phenomenon connected to Central Europe, even though it is officially regarded as a master degree by the Czech Ministry of Education. I also did not consider different language mutation of the very same programme (it is considered as one accreditation case). 
Table 1 Reasons for not granting accreditation

\begin{tabular}{|l|l|l|l|l|l|}
\hline Year & $\begin{array}{l}\text { Negative } \\
\text { recommendations }\end{array}$ & $\begin{array}{l}\text { Academic } \\
\text { staff }\end{array}$ & $\begin{array}{l}\text { Program } \\
\text { guarantor }\end{array}$ & $\begin{array}{l}\text { Curricular } \\
\text { issues }\end{array}$ & Other \\
\hline 2015 & 62 & 40 & 23 & 36 & 16 \\
\hline 2014 & 67 & 45 & 20 & 34 & 20 \\
\hline 2013 & 64 & 52 & 27 & 36 & 14 \\
\hline 2012 & 98 & 57 & 26 & 50 & 37 \\
\hline 2011 & 104 & 70 & 22 & 56 & 32 \\
\hline 2010 & 106 & 77 & 2 & 65 & 25 \\
\hline 2009 & 112 & 62 & & 70 & 30 \\
\hline 2008 & 120 & 66 & & 85 & 12 \\
\hline 2007 & 105 & 40 & & 80 & 17 \\
\hline 2006 & 74 & 36 & & 45 & 25 \\
\hline 2005 & 54 & 29 & & 39 & 5 \\
\hline 2004 & 63 & 17 & & 51 & 9 \\
\hline 2003 & 68 & 37 & & 48 & 11 \\
\hline 2002 & 121 & 35 & & 36 & 64 \\
\hline
\end{tabular}

Source: by author

Westerheijden (2001) regards such a system of programme accreditation focusing on standards for inputs (academic staff, curriculum plans, facilities) as 'first generation accreditation' system, which was implemented in mid-90s in Central and East European Countries. It was caused by the situation in the region as the minimum quality levels had to be redefined after the fall of communism (Van der Wende andWesterheijden 2003). This could have been used as an excuse in the 90s, but the accreditation system in the Czech Republic should have been changed much sooner than in 2016.

Kohoutek (2014) proposed replacing the programme accreditation scheme by a quality audit. The Czech accreditation system has been finally altered by the Higher Education Act amendment, which will be analysed in the following section.

\section{Higher Education Act amendment}

The Czech parliament has recently approved an amendment of the Higher Education Act. According to the amendment the institutional accreditation is introduced, which means that institutions of higher education now have a chance to be accredited as a whole. The programme accreditation still remains as an option. Under such a scheme a university will be able to receive the institutional accreditation for a particular subject area(s) and will be eligible to offer degree programmes within the designated subject area without being obliged to have each study programme accredited separately. The accreditation will be granted for 10 years (in some specific cases for 5 years only) based on a detailed self-evaluation submitted by the respective institution (Senátparlamentu Českérepubliky 2016).

Standards for the institutional accreditation include requirements for the institutional environment, particularly requirements for a strategy and university governance, study programmes and its students, research, international cooperation, student internships, academic staff members, university resources. Universities seeking institutional accreditation are required to establish a Council for internal assessment as the key body conducting and monitoring the process of internal quality management (Senátparlamentu Českérepubliky 2016).

There are also be requirements for the study programme within the specific subject area, particularly for the specialisation of the study programme, profile of the graduate, professional knowledge and skills with regard to the respective subject area, requirements for the academic staff, resources supporting the programme, international cooperation and student internships, equal access for handicapped applicants and students to the higher education must be guaranteed (Senátparlamentu Českérepubliky 2016).

Universities still have the responsibility to designate guarantors for the individual programmes. While the requirements for the master programme guarantor remain the same (full time academic staff member having a minimum rank of assoc. professor), the requirements for the bachelor programme guarantor have been softened. 
Under the new scheme also a fulltime academic staff member having a doctoral degree will be eligible to guarantee a bachelor programme.

National Accreditation Bureau for Higher Education (hereinafter National Accreditation Bureau) has been established as a new quality assurance body, instead of the Accreditation Commission. National Accreditation Bureau is technically an organisation unit of the ministry but the office is expected to be completely independent regarding its decision-making. National Accreditation Bureau makes decisions especially on the institutional accreditation, also on programme and other accreditations. The head officer of the body is the Chairperson of National Accreditation Bureau who appoints the evaluation committees to conduct the evaluation and assessment. The Council of National Accreditation Bureau consisting of 15 members serves as the executive body of National Accreditation Bureau (Senátparlamentu Českérepubliky 2016). All members of the council, including the chairperson, have been already appointed.

The rights of National Accreditation Bureau should be stronger compared its predecessor. Previously, Accreditation Commission could only take an official stance but the newly established body will be able to make the ultimate decision on granting accreditation. The role of the ministry will be diminished under such a scenario and the National Accreditation Bureau will become the supreme regulator of the higher education market in the country.

This proposed step towards the institutional accreditation process is certainly moving in the right direction as it should decrease the administrative burden related to the current programme accreditation. Institutional accreditation should also strengthen the internal mechanisms of quality control, which are more important for the daily operations of the university than the external ones. Good universities, though, conduct an internal quality evaluation already without any external coercion. Moreover, it is not guaranteed that the newly established body Council for internal assessment itself would increase the efficiency of the internal quality assurance process. However, the option of the institutional accreditation emphasizing the internal quality management is a step in the right direction in the long run.

Another significant change introduced by the amendment is abolishment of the fields of study (within the study programmes), which should make the system clearer and easier to understand. However, there is a transition period as all study programs and fields accredited under the former scheme remain automatically accredited at least for another three years ${ }^{3}$ (Senátparlamentu Českérepubliky 2016).

The amendment keeps the requirement of the programme guarantor, so all the described issues connected to the phenomena remain unsolved. Moreover, it could undermine the main philosophy of the institutional accreditation, under which the institution is assessed and accredited as a whole. The amendment designates 37 subject areas, for which universities may receive the institutional accreditation. It means that for instance a university might be found eligible for a certain subject area (and would be allowed to offer any relevant degree program) but it might not be found eligible in terms of another subject area. Therefore, the system may be actually called a system of 'subject area accreditation' rather than 'institutional accreditation'. Moreover, universities are required to have at least one programme belonging to the respective subject area already accredited for 10 years at the time of application, which excludes some applications right from the beginning. Again, I see no rationale behind such a requirement. It seems that the system has been designed mainly for the established big public universities. Finally, the issue of learning outcomes is not explicitly handled by the amendment.

The amendment became effective as of 1 September 2016. At the moment, it is hard to predict how the new accreditation system shall work in practice especially with regard to the approach of the accreditation officials towards various universities and specific accreditation cases.

The National Accreditation Bureau has been already operating for more than one year. However, the new body has been so far dealing mainly with finalizing new accreditation methodology and guidelines, and also with pending issues from the former period related to individual programmes of study. Recently, first applications for institutional accreditation of big public universities have been evaluated. It still very soon to provide any comprehensive analysis of the new accreditation system. Thus, it still too soon to judge, whether we will really shift from the input-based system to an improvement-based system paying attention to student learning, or not

${ }^{3}$ From the moment the law became effective 


\section{Role, value and policy perspective of accreditation}

It is widely believed that the quality assurance is the main and essential role of accreditation, but we shouldn't omit other roles performed by the accreditors. As the major fraction of the money spent on higher education in the Czech Republic is from public sources, the implicit task for the accreditor is to make sure that the government money invested to higher education is spent properly, i.e. to well-functioning institutions and programmes. Czech public universities still receive the majority of their funding based on the number of students enrolled. Therefore, if a university loses accreditation for one of its high enrolment degree programmes, it can have a significant financial impact.

Another role of accreditation is to provide a signal to the employers in the labour market that the university graduate possesses the relevant knowledge, skills and competencies. In the case that there is persistent long-term unemployment of university graduates, it may suggest that the money invested into the higher education (to a particular institution or its programme) was not spent efficiently as any unemployed person causes burden for the state social system.

In several cases, ACCR failed to perform the role for the labour market as the graduates of some institutions hardly possess the appropriate knowledge, skills and competencies expected from a university graduate. In the period from 2008 and 2012, only 60,4\% of master university graduates started their professional carrier in occupations, where the respective university degree (level and field of study) was expected (Koucký et al. 2014). This number cannot be attributed to the world financial crisis only. Obviously, no one can blame for instance a private for-profit university for offering such a degree programme if there is enormous student demand and if it was officially approved by ACCR and the ministry. It would be the same like if we were to blame an entrepreneur, regardless of the branch, that his/her products are highly demanded.

The issue connected with the government assuring the quality regardless of the branch is that if that's the case people care much less about the actual quality of the goods and services, which is obviously favourable to the ones offering lower quality than the others. In the case of higher education, the beneficiaries are the low-quality universities and their graduates with officially accredited programmes by the ministry as at the end of the day the graduates do have a degree from an officially accredited programme.

The issue described in the prior paragraph is a paraphrase of the Gresham's law, which refers to monetary policy but describes an analogous problem in principle. The law basically says that money overvalued artificially by government will drive out of circulation artificially undervalued money (Rothbard 2010). In our case, bad education would drive out the good education. Westerheijden (2010) gives as a specific example a government policy, which puts a premium on graduation as many students as possible.

Under the current scheme in the Czech Republic, where $77 \%$ of expenditures on higher educational institutions are made from public sources (OECD 2016), the significant role of the government (through the accreditation body) may be considered justifiable.

$\mathrm{ACCR}^{4}$ could be also perceived as the regulator of the higher education market in the country. So, let's consider also some further economic policy perspectives related to accreditation of higher education, such as economic regulation theory and the principal-agent problem. The original idea of economic regulation, dated to the beginning of the former century, was that certain industries considered at that time to be naturally monopolistic must be regulated for the public interest, i.e. in order to protect consumers. The later empirical work of Stigler (1971) and Posner (1974), however, has shown that regulation was not conducted in the public interest but rather in favour of inefficient firms within the industry to protect them against the new competitors. In economic literature, capture theory is the term which describes when the regulatory body is actually dominated by the 'regulated' firms. Accreditation organizations in general (in this case ACCR) possess the right (delegated from their principal, i.e. the Czech government) to regulate the entry into the higher education market. The necessity to obtain accreditation can be certainly seen as a barrier to entry into the higher education market. The principalagent problem is caused by the fact that the principal cannot always fully oversee the action of the agent so the agent very often acts in its own self-interest rather than in the principal's interest. In general, the principal can be broadly described as someone (some party) who delegates work (rights) to someone else - the agent. The agent acts on behalf of the principal then.

\footnotetext{
${ }^{4}$ Now the new body National Accreditation Bureau
} 
As briefly suggested above, in the case of Czech accreditation, the principal was the Czech government and the agent was the ACCR. In a broader sense the whole higher education community can be regarded as the second principal. Accreditation also serves as a consumers' protection correcting the information asymmetry (Blackmur 2010; Dill 2010). It provides relevant information, not only to the potential employers as pointed out above, but also to prospective students (or their parents), who can be regarded as investors to human capital through higher education.

In accordance with the Human Capital Theory developed and finalised explicitly by Gary Becker (1962), people (in the case of higher education, university students) invest into their human capital through education or additional training in order to get future benefits from such an investment. The theory says that salaries, wages differentials reflect knowledge and skills, i.e. amount of human capital accumulated and possessed by the respective employee. When translated to 'accreditation language', this means that student learning outcomes is what matters most. I regret to say that the learning outcomes aspect have been neglected by the Czech accreditation policy so far.

\section{Conclusion}

Czech accreditation so far has not focused on quality assurance processes and learning outcomes but rather on the quality of input into the teaching process. Empirical evidence shows that main reasons for not granting accreditation were unsatisfactory credentials of the academic staff and issues related to the proposed programme curriculum. No attention has been paid to the process of internal quality assurance and the student learning outcomes.

The former scheme of the programme accreditation in the Czech Republic was no longer sustainable due to the reasons described in the previous text, i.e. not only the unreasonable administrative demand of the current system but mainly the emphasis given to inputs rather than outputs and its unfavourable approach towards private universities caused by the requirement for the programme guarantor accompanied by the system of promotion to the highest academic ranks in the country. Academic ranks and credentials of the academic staff definitely matter as the academic staff members having higher academic ranks possess stronger academic experience and publication records, which are certainly prerequisites for good instruction. This, however, does not necessarily guarantee better student learning outcomes. Universities need to make sure that student learning outcomes are analysed and eventually met through well-functioning internal management quality system.

The step towards the institutional accreditation scheme is certainly moving in the right direction as it should decrease the administrative burden related to the current programme accreditation. Institutional accreditation should also strengthen the internal mechanisms of quality control, which are more important for the daily operations of the university than the external ones. It could mean a certain convergence towards the accreditation model used in the United States or Western Europe, where the universities are expected to manage the quality internally themselves.

However, the new Czech accreditation scheme also brings several concerns, which could undermine the main philosophy of the institutional accreditation scheme, such as the subject area approach and the persisting programme guarantor requirement. National Accreditation Bureau has just officially assessed few big public universities for institutional accreditation, it is still not clear how the new accreditation system shall work in practice. The most important question to answer is what will be the main criterion for (not) granting the accreditation exercised by the accreditation officials, and whether we will really shift to a system paying attention to student learning, or all the declared changes will be only formal.

\section{References}

Accreditation Commission Czech Republic. (2015). Accreditation Commission Standards for assessment of applications for granting, expanding and extending accreditation of study programmes and their fields of study. (http://www.akreditacnikomise.cz/attachments/article/83/EN_Standards\%20for\%20study\%20programmes_2_ 2015.pdf). Accessed 27 October 2015.

Accreditation Commission Czech Republic. (2014). Bachelor and master study programmes forms for filing an application for accreditation, expansion and extension of accreditation.

(http://www.akreditacnikomise.cz/cs/nalezitosti-zadosti.html). Accessed 21 October 2014. 
Akreditačníkomise Českárepublika - Zápisy ze zasedání. (n.d.). Accessed 9 December, 2016, from https://www.akreditacnikomise.cz/cs/zapisy-ze-zasedani.html

Alderman, G. (2005). Compliance or Quality? American and British approaches to the accreditation of higher education institution. College and University, 81(1), 17-22.

Becker, G. (1962). Investment in Human Beings. Journal of Political Economy, 70(5), 9-49.

Blackmur, D. (2010). The public regulation of higher education qualities: Rationale, processes, and outcomes. In D. F. Westerheijden, B. Stensaker, \& M. J. Rosa (Eds.), Quality assurance in higher education (pp. 15-45). Dordrecht: Springer.

Dill, D. (2010). Will market competition assure academic quality? In D. F. Westerheijden, B. Stensaker, \& M. J. Rosa (Eds.), Quality assurance in higher education (pp. 47-72). Dordrecht: Springer.

Kohoutek, J. (2014). Analysing instrument mixes in quality assurance: the Czech and Slovak Accreditation Commissions in the era of mass higher education. Quality in Higher Education, 20(1), 83-102.

Koucký, J., Ryška, R., \&Zelenka M. (2014). Reflexevzdělání a uplatněníabsolventůvysokýchškol: Výsledkyšetření REFLEX 2013 [Reflexion of Education and Employability of University Graduates: Research Findings REFLEX 2013].Praha:StřediskovzdělávacípolitikyPedagogickéfakultyUniverzity Karlovy.

OECD. (2016). Education at a Glance 2016: OECD Indicators. Paris: OECD Publishing.

Posner, R. (1974). Theories of Economic Regulation. The Bell Journal of Economics and Management Science, 5(2), $335-58$.

Rothbard, M. (2010). What Has Government Done to Our Money? Auburn: Ludwig von Mises Institute.

Šebková, H. (2009). The European standards and guidelines in quality assurance mechanisms in the Czech Republic. In J. Kohoutek (Ed.), Implementation of the standards and guidelines for quality assurance in higher education in the Central and East-European countries - Agenda ahead (pp. 201-234). Bucharest: UNESCO-CEPES.

Šebková, H. (2007). Czech quality assurance: The task and responsibilities of accreditation and evaluation. In S. Schwarz,\& D.F. Westerheijden (Eds.), Accreditation and evaluation in the European higher education area (pp. 65-86). Dordrecht: Springer.

SenátparlamentuČeskérepubliky. (2016). Návrhzákona, kterým se měnízákon č. 111/1998 Sb., o vysokýchškolách a o změně a doplněnídalšíchzákonů (zákon o vysokýchškolách), vezněnípozdějšíchpředpisů, a některédalšízákony [Higher Education Act Amendment].

(http://www.senat.cz/xqw/xervlet/pssenat/historie?cid=pssenat_historie.pHistorieTisku.list\&forEach.action=d etail\&forEach.value=s3822)Accessed 12 March 2016.

Stigler, G. (1971). The theory of economic regulation. The Bell Journal of Economics and Management Science, 2(1), 3-21.

Van der Wende, M., \&Westerheijden, D. (2003). Degrees of trust or trust of degrees? Quality assurance and recognition. In J. File, J., \&L.Goedegebuure (Eds.), Real-time systems. Reflections on higher education in the Czech Republic, Hungary, Poland and Slovenia (pp. 177-206). Brno: Vutium.

Westerheijden, D. (2001). Ex OrienteLux?: National and multiple accreditation in Europe after the fall of the wall and after Bologna. Quality in Higher Education, 7(1), 65-75.

Westerheijden, D. (2010). States and Europe and quality of higher education. In D. F. Westerheijden, B. Stensaker, \& M. J. Rosa (Eds.), Quality assurance in higher education (pp. 73-95). Dordrecht: Springer. 